原 著

\title{
特発性全般てんかんにおける断薬の可能性について
}

\section{Withdrawal of Antiepileptic Drugs in Patients with Idiopathic Generalized Epilepsy}

\author{
川崎淳* 兼本浩祐白坂幸義河合逸雄
}

\begin{abstract}
要旨：特発性全般てんかんと診断され、発作消失から 2 年以上経過し、当院において 断薬を試みた症例を後方視的に検討した。減量中もしくは断薬後 1 年以内に再発した ものは 36 例中 12 例 (33\%) であった。再発する危険が高い因子は、発症年齢が 13 歳 以上 18 歳未満 $(p<0.005)$ 、罹病期間が 4 年以上 $(p<0.05)$ 、発症から発作消失す るまでに出現した全般性強直間代発作 $(\mathrm{GTC})$ の回数が 6 回以上 $(\mathrm{p}<0.05)$ 、若年性

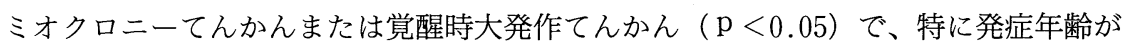
13 歳以上 18 歳未満のものは 9 例のうち 7 例が再発した。またミオクロニー発作や覚 醒時の GTC を持つ症例では再発の危険が高い傾向にあった。抗てんかん薬の減量は、 特発性全般てんかんにおいても、危険因子の有無を考慮して慎重に判断すべきである ことが示唆された。

てんかん研究 $1997 ; 15: 1-6$
\end{abstract}

Key Words : idiopathic generalized epilepsy, antiepileptic drug, withdrawal, recurrence, risk factor

（受付：1996 年 5 月 31 日、第 1 回訂正：1996 年 7 月 26 日、第 2 回訂正 $： 1996$ 年 9 月 2 日、第 3 回訂正：1996 年 10 月 7 日、受理：1996 年 10 月 7 日）

はじめに

発作の消失した患者のうちいかなる症例に対し て断薬が可能であるかはてんかんの診療上非常に 重要な問題である。従来の報告においては、対象 が全般てんかん、局在関連てんかんのいずれも含 んでいるために、再発に関係する因子が明確にさ れにくい傾向にあった。そこで今回われわれは断 薬が一番問題になると思われる特発性全般てんか んに対象を限定し、どのような症例に対して断薬 が可能であるかを検討したのでこれを報告する。

\section{対象および方法}

1983 年 12 .月以降に当院に受診した患者で特発 性全般てんかんと診断され、発作消失から 2 年以 上経過したのちに当院において断薬を試みたもの のうちで、断薬の成否が明らかな 36 例を対象とし た。特発性全般てんかんの定義は定型欠神発作、 ミオクロニー発作、GTC 以外の発作を持たず、脳 波上 $3 \mathrm{~Hz}$ 以上の全般性棘徐波または多棘徐波を 示すものとした。

対象例の分類診断は、小児欠神てんかんが 5 例、 若年性欠神てんかんが 5 例、若年性ミオクロニー てんかんが 8 例、覚醒時大発作てんかんが 3 例で、

* 国立療養所宇多野病院 関西てんかんセンター

〔于 616 京都市右京区鳴滝音戸山町 8 ]

Jun Kawasaki, Kousuke Kanemoto, Yukiyoshi Shirasaka, Itsuo Kawai

Utano National Hospital, Kansai Regional Epilepsy Center 
その他の特発性全般てんかんが 15 例見られた。

発作型は GTC が 32 例、欠神発作が 12 例、ミ オクロニー発作が 9 例であった。GTC のなかで 特に覚醒時の GTC は 9 例に見られた。発作型の 組み合わせを見ると、欠神発作のみの症例が 4 例 で、他の 32 例はすべて GTC を有していた。この うち 16 例は GTC のみで、8 例がミオクロニー発 作と GTC、 7 例が欠神発作と GTC、1 例がミオ クロニー発作、欠神発作と GTC の組み合わせで あった。なおミオクロニー発作を持つ 9 例のうち 5 例で GTC は覚醒中に出現していた。

減量前に投与されていた薬凨について見ると、 valproic acid (VPA) が 29 例と最も多く、次い で phenobarbital (PB) の 12 例で、以下 phenytoin (PHT) 3 例、primidone (PRM)、 ethosuximide $(\mathrm{ESM})$ 、carbamazepin $(\mathrm{CBZ})$ 、 clonazepam (CZP) 各 1 例であった。組み合わせ を見ると、単剤投与の 26 例のうち VPA 19 例、 $\mathrm{PB} 5$ 例、ESM、CBZ 各 1 例であった。多剤投与 の 10 例は全て VPA を含み、VPA と $\mathrm{PB}$ が 6 例、VPA と PHT を含む組み合わせが 3 例、VPA と CZP が 1 例であった。

主な投与薬剤である VPA と PB の投与量と血 中濃度は以下の通りである。

VPA については投与量が 1 日 $400 〜 1,600 \mathrm{mg}$ 、 平均 $770 \mathrm{mg}$ で、血中濃度は $25.2 \sim 106.7 \mu \mathrm{g} / \mathrm{m} l$ 、 平均 $62.6 \mu \mathrm{g} / \mathrm{m} l$ であった。PB については投与 量が 1 日 30 90 mg、平均 $58 \mathrm{mg}$ 、血中濃度は 5.4 $\sim 27.1 \mu \mathrm{g} / \mathrm{m} l$ 、平均 $15.0 \mu \mathrm{g} / \mathrm{m} l$ であった。

なお減量を開始する基準は上記の特発性全般て んかんの定義を満たし、発作が 2 年以上消失して いるもので、本人に対して減量による利益と不利 益を十分に説明し、減量することに同意を得られ た症例である。同意の得られなかった症例には減 量を行っていない。

具体的な減量方法について下記に述べる。

各薬剤について 1 回の減量する量は原則として 下記の通りである。減量する間隔は最低 1 力月と したが多くは 1 年である。

VPA $200 \mathrm{mg}$

PB $15 \mathrm{mg}$

PRM $125 \mathrm{mg}$

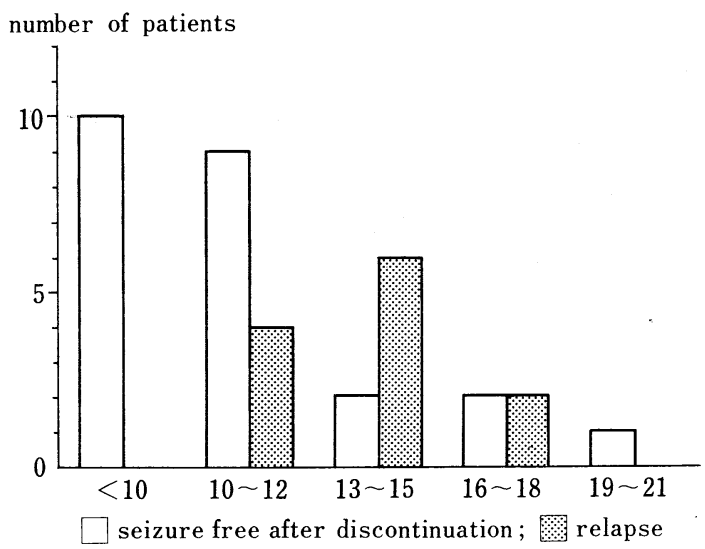

Fig. 1 Relapse related to age at onset

PHT $25 \mathrm{mg}$

ESM $150 \mathrm{mg}$

CBZ $100 \mathrm{mg}$

CZP $0.5 \mathrm{mg}$

なお PHT については血中濃度が $5 \mu \mathrm{g} / \mathrm{m} l$ 以下 となった時点で中止した。

36 例のうち減量中もしくは断薬後 1 年以内に 発作が再発したものを再発群、断薬後 1 年の時点 で発作の再発しなかったものを非再発群とし、家 族歴、既往歴、発症年齢、最終発作年齢、減量開 始時の年歯、発症から発作消失までの期間、発作 消失から減量開始までの期間、発作型、投薬内容、 脳波所見などについて比較検討した。

なお PB、PRM、CZP を減量または中止したの ち、1 1 月以内に発作の出現した症例は反跳発作 が誘発された可能性があると考え対象から除外し た。

有意差の検定には $\chi^{2}$ 検定を使用した。 また多変量解析も試みた。

\section{結 果}

対象となった 36 例のうち、減量中もしくは断薬 後 1 年以内に再発したものは 12 例で、再発率は $33 \%$ であた。減量中に再発したもの 9 例、断薬 後に再発したものが 3 例であった。減量または断 薬から再発までの期間は 2 例を除いて 2 カ月から 1 年 10 力月 (平均 8.4 力月) であった。 3 週間で 再発したものが 2 例あり、いずれも VPA を減量 
number of patients

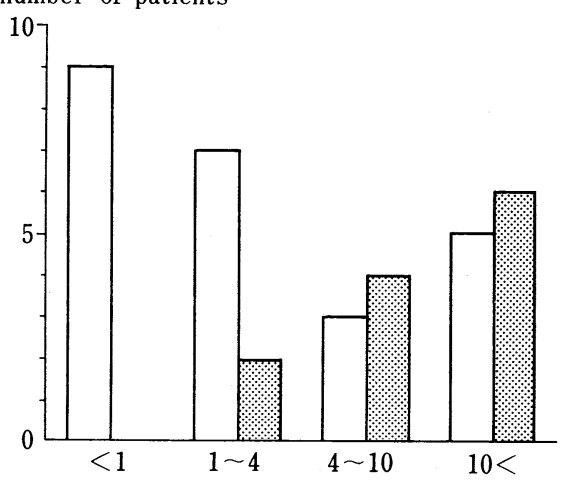

$\square$ seizure free after discontinuation; 7 relapse

Fig. 2 Relapse related to duration of illness

\section{もしくは中止していた。}

家族歴としては 3 親等以内の熱性痙卛、てんか んを取り上げたが、いずれも 2 群間で有意差は見 られなかった。熱性痙攣の既往歴も2 群間に有意 差を認めなかった。

発症年齢には顕著な差が見られ、Fig. 1 に示す ように 10 歳未満で発症した 10 例はすべて発作の 再発は見られなかった。発症年齢が 10 歳以上では 再発するものが見られるが、特に多いのは 13 歳以 上の症例で、13 歳以上 18 歳未満の 9 例のうち 7 例が再発している。発症年齢が 18 歳以上の症例は 数が少ないため明確なことは言えなかった。

次に罹病期間であるが Fig. 2 に示すように、発 症後 1 年以内に発作が消失した症例には再発は見 られず、 4 年以内に発作が消失した症例も再発は 少なかった。逆に 4 年以上発作の消失しなかった 症例については再発の危険が高いという結果が得 られた。減量を開始した年齢と発作が消失してか ら減量を開始するまでの期間はいずれも有意差は 見られなかった（Table 1)。

減量を開始する前の脳波では全般性の棘徐波が 見られたものと見られなかったものとで差は見ら れなかった。減量を開始する前の薬剤数では 1 剤 のものはやや再発率が低かったが有意差は見られ なかった (Table 1)。

減量を開始する前の薬剤のうち、投与された症 例の多かった VPA と PB について検討した。 VPA の投与量は再発群で $980 \mathrm{mg} /$ 日、非再発群
Table 1 Predictive factors for relapse on withdrawal

\begin{tabular}{|c|c|c|c|}
\hline factor & $\begin{array}{l}\text { relapse } \\
\text { number }\end{array}$ & $\%$ & \\
\hline \multicolumn{4}{|l|}{ age at onset (yesrs) } \\
\hline $13 \sim<18$ & $7 / 9$ & 78 & \\
\hline other & $5 / 27$ & 19 & $\mathrm{p}<0.005$ \\
\hline \multicolumn{4}{|l|}{ duration of illness (years) } \\
\hline $0 \sim<4$ & $2 / 18$ & 11 & \\
\hline $4 \sim$ & $10 / 18$ & 56 & $\mathrm{p}<0.05$ \\
\hline \multicolumn{4}{|c|}{ age at start of withdrawal (years) } \\
\hline $10 \sim<20$ & $3 / 15$ & 20 & \\
\hline $20 \sim$ & $9 / 21$ & 43 & n. s. \\
\hline \multicolumn{4}{|l|}{ period seizure free (years) } \\
\hline$<3$ & $7 / 14$ & 50 & \\
\hline $3 \sim$ & $5 / 22$ & 22 & n. s. \\
\hline \multicolumn{4}{|l|}{ EEG before withdrawal } \\
\hline spike \& wave & $2 / 9$ & 22 & \\
\hline no epileptic discharge & $10 / 27$ & 37 & n. s. \\
\hline \multicolumn{4}{|l|}{ number of drugs } \\
\hline 1 & $6 / 26$ & 23 & \\
\hline $2 \sim$ & $6 / 10$ & 60 & n. s. \\
\hline \multicolumn{4}{|l|}{ number of GTC } \\
\hline $1 \sim 5$ & $3 / 18$ & 17 & \\
\hline $6 \sim$ & $8 / 12$ & 67 & $\mathrm{p}<0.05$ \\
\hline \multicolumn{4}{|l|}{ combination of seizures } \\
\hline No & $5 / 20$ & 25 & \\
\hline Yes & $7 / 16$ & 44 & n. s. \\
\hline \multicolumn{4}{|l|}{ epileptic syndromes } \\
\hline JME or GTCa & $7 / 11$ & 64 & \\
\hline others & $5 / 25$ & 20 & $\mathrm{p}<0.05$ \\
\hline
\end{tabular}

で $640 \mathrm{mg} /$ 日と差が見られたが、血中濃度は再発 群が $63.1 \mu \mathrm{g} / \mathrm{m} l$ 、非再発群が $62.3 \mu \mathrm{g} / \mathrm{m} l$ と全く 差が見られなかった。PBについては投与量、血中 濃度とも両群間に差は見られなかった。

発症から発作消失するまでに出現した GTCの 回数を見ると 5 回以下のものは 6 回以上のものと 比較して有意に再発率が少なかった (Table 1)。

発作型が 1 型のものと 2 型以上のものを比較し たが、再発率に有意差は認められなかった。また ミオクロニー発作や覚醒時の GTC を持つ症例で 再発の危険が高い傾向にあった (Fig. 3)。

てんかんの症候群分類で見ると、若年性ミオク ロニーてんかんもしくは覚醒時大発作てんかんと 


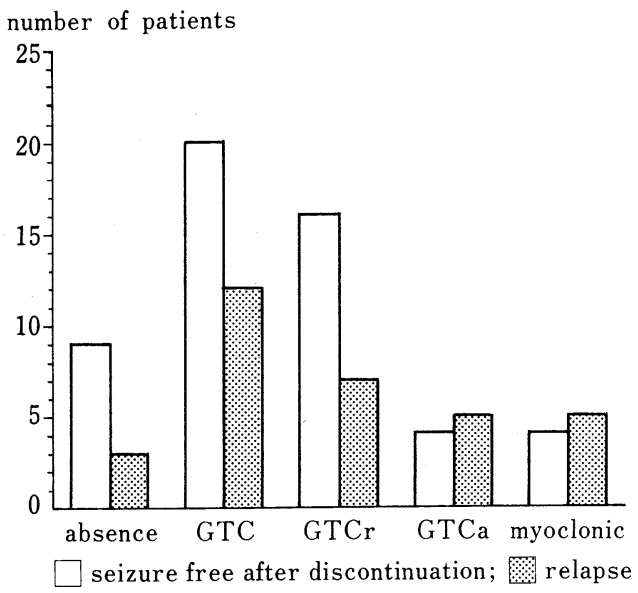

Fig. 3 Relapse related to seizure type Abbreviations: GTC, generalized tonic clonic seizure; GTCr, GTC at random GTCa, GTC on awakening

分類された症例はそれ以外のてんかん症候群の症 例に比較して再発率が有意に高かった（Table 1)。

再発する危険が高い因子 4 項目について、さら に詳細に検討した。回帰分析により 4 項目全てを 考慮した場合に、再発の予測性に関して有意な回 帰が得られた $(\mathrm{p}<0.01)$ 。しかし単独の項目では 有意な回帰が得られずしいて挙げるなら罹病期間 が $\mathrm{p}=0.08$ でやや有意な傾向が見られた。また再 発を従属変数、4 項目を独立変数として logistic linear analysis を行ったところ、独立変数間には 有意な連関は見られなかった。以上より多変量解 析では $\chi^{2}$ 検定で得られた結果以上の情報は得ら れなかった。

\section{考 察}

発作がある一定期間消失した症例に対して抗て んかん薬の減量中止が可能かどうかは日常の臨床 の中で極めて重要な問題である。これについての 研究は数多くなされているが、結果については大 きなばらつきがある ${ }^{1,2)}$ 。たとえば再発率について は $10 \%$ から $70 \%$ までの報告がある ${ }^{2)}$ 。これは研究 により対象となる症例が異なるためと考えられ る。したがって再発に関わる因子についても意見 の相違がある。様々な因子について今までの研究
と本研同を比較検討してみる。

まず発症年齢であるが、多くの研究では小览期 発症の方が思春期発症に比較して再発が少ないと いう結果を示している 両者に差がないとしているものもある7)。多くの 研究ではてんかん分類別に検討を行っていないた め、特発性全般性てんかんにおいて差があるか否 かは不明である。

本研究では小児期発症の症例は再発が少ないの に対し、思春期発症の症例は極めて再発率が高く、 80\%に抢よぶという結果となった。これは Janz ${ }^{8)}$ の思春期発症の原発性全般てんかんでは極めて再 発する危険が高いと述べていることと一致する。 思春期発症の原発性全般てんかんについては Pestre ら ${ }^{9)}$ の報告でも最終的に $80 \%$ 以上と高い 再発率を示している。同じ特発性全般てんかんで も発症年齢によって再発率に大きな差が見られる と考えられる。

次に罹病期間についてであるが、多くの研究に おいて短いほうが再発率が低いという結果が示さ れている ${ }^{1,3,49}$ 。本研究においても発症から 4 年以 内に発作が消失したものは再発が少ないという結 果が出ており、このことは特発性全般てんかんに も当てはまると考えられる。

GTC の合計回数と再発との関連では、Emerson ら $^{10)}$ が 20 回以下の群と 30 回以上の群で再発 率に差があることを指摘している。これに対し

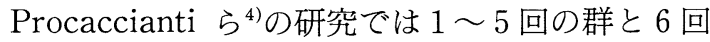
以上の群で有意差を指摘している。われわれの今 回の研究は後者と一致した結果となった。

発作型との関連については以前からあまり明確 な関連は指摘されていない音。これは多くの発作 はいくつかのてんかん症候群に共通して見られる ため、一定した結果が得られないのではないかと 考えられる。今回の研究でも発作型による有意差 は見られなかった。ただミオクロニー発作と、覚 醍時大発作は再発率が高い傾向にあった。これら の発作については $\mathrm{Jan}^{8)}$ も再発の危険が高いこ とを指摘している。対象を特発性全般てんかんに 限定したためミオクロニー発作をもつ症例は若年 性ミオクロニーてんかんの症例にほぼ重なり、単 なる大発作ではなく、覚醒時大発作を持つ症例は 
若年性ミオクロニーてんかんと覚醒時大発作てん かんにほぼ限られるため、再発の危険が高いとい う結果が出たと考えられる。減量前の脳波異常に ついては小児を対象にした研究では再発の危険が 大きいと言われている ${ }^{1,9,11,12)}$ 。しかし成人を対象 にした研究でははっきりした結論は得られていな い。本研究では小児期発症の症例も多かったが、 減量を開始した時期はほとんどが成人に達してか らであるため脳波異常との関連が少なかったのか も知れない。また局在関連てんかんと特発性全般 てんかんでは脳波と再発の関連は異なる可能性も ある。今後の検討課題である。

若年性ミオクロニーてんかんや、覚醒時大発作 てんかんで断薬後の再発率が高いことは Janz ${ }^{8)}$ も指摘している。今回は症例数が少ないため、若 年性ミオクロニーてんかん単独もしくは覚醒時大 発作てんかん単独では再発率に有意差は見られな かった。両者を合わせると症例数が増加したため 有意差が見られたと考えられる。これらの症例数 が少なかった原因としては、以前より再発作が高 いことが指摘されているため、本人が強く減量を 希望した場合しか減量を試みていないことが考え られる。

多変量解析で $\chi^{2}$ 検定で得られた結果以上の情 報は得られなかったが、これは症例数が少ないこ とが一つの原因と考えられる。今後症例数がさら に増えれば、多変量解析により詳細な検討が可能 になると考えられた。

特発性全般てんかんでも思春期に発症するも の、4 年以内に発作が消失しないもの、GTC の合 計回数が 6 回以上のものは減量した場合の再発の 危険が極めて高いことが示唆された。これらに該 当する患者さんに薬の減量を希望された場合は再 発の危険を十分に伝える必要があると思われる。

稿を終えるにあたり本研究にご協力いただきました京都 大学精神科神経科 扇谷 明先生ならびに北野病院小児科 中川嘉洋先生に深謝いたします。

\section{文献}

1) Gross-Tsur V, Shinnar S. Discontinuing antiepile- ptic drug treatment. In : Wylline E, ed. Treatment of epilepsy : principles and practice. Philadelphia : Lea \& Febiger, 1993 : 858-866.

2) Berg AT, Shinar S. Relapse following discontinuation of antiepileptic drugs : a meta-analysis. Neurology $1994 ; 44: 601-608$.

3) Holowach-Thurston J, Thurston DL, Hixon BB, Keller AJ. Prognosis of childhood epilepsy : additional follow-up of 148 children 15 to 23 years after withdrawal of anticonvulsant therapy. N Engl J Med $1982 ; 306: 831-836$.

4) Procaccianti E, Lugaresi P, Tinuper A, Serracchioli A, Ripamonte L, Baruzzi A. Antiepileptic drug withdrawal : preliminary results of a prospective study. Adv Epileptol $1987 ; 16$ : 379-382.

5) Medical Research Council Antiepileptic Drug Withdrawal Study Group. Randomised study of antiepileptic drug withdrawal in patients in remission. Lancet $1991 ; 337:$ 1175-1180.

6) Shinar S, Berg AT, Moshe SL, Kang H, O'Dell C, Alemany $\mathrm{M}$, et al. Discontinuing antiepileptic drugs in children with epilepsy : prospective study. Ann Neurol $1994 ; 35: 534-545$.

7) Callaghan N, Garrett A, Goggin T. Withdrawal of anticonvulsant drugs in patients free of seizures for two years: a prospective study. $\mathrm{N}$ Engl J Med $1988 ; 318: 942-946$.

8) Janz D. When should antiepileptic drug treatment be terminated ? Adv Epileptol $1987 ; 16: 365-372$.

9) Pestre M, Loiseau P, Larrieu E, Dartigues JF, Cohadon S. Withdrawal of antiepileptic drug therapy in adolescent epileptic patients. Adv Epileptol $1987 ; 16: 395-400$.

10) Emerson R, D'Souza BJ, Vining EP, Holden KR, Mellits ED, Freeman JM. Stopping medication in children with epilepsy : predictors of outcome. N Engl J Med 1981 ; 304 : 1125-1129.

11) Matricardi M, Brinciotti M, Benedetti P. Outcome after discontinuation of antiepileptic drug therapy in children with epilepsy. Epilepsia $1989 ; 30: 582-$ 589.

12) Gherpelli JLD, Kok F, dal Forno S, Elkis LC, Lefevre BHW, Diament AJ. Discontinuing medication in children : a study of risk factors related to recurrence. Epilepsia $1992 ; 33$ : 681-686. 


\title{
Summary
}

\section{Withdrawal of Antiepileptic Drugs in Patients with Idiopathic Generalized Epilepsy}

\author{
Jun Kawasaki, Kousuke Kanemoto, Yukiyoshi Shirasaka, Itsuo Kawai
}

We studied risk factors of relapse after antiepileptic drug withdrawal in a retrospective analysis of 36 patients with idiopathic generalized epilepsy. These patients had been free of seizures for at least 2 years. Twelve patients (33\%) experienced a recurrence $<1$ year after discontinuation or during antiepileptic drug withdrawal. Risk factors statistically related to seizure recurrence were as follows: onset in adolescence $(13-18$ years old $)(p<0.005) ;>4$ years duration of illness $(p<0.05) ;>5$ generalized tonic clonic seizures before control $(\mathrm{p}<0.05)$; juvenile myoclonic epilepsy or epilepsy with grand mal seizures on awakening $(p<0.05)$. We conclude that these risk factors are decisive in judging whether antiepileptic drugs should be discontinued or not in patients with idiopathic generalized epilepsy.

J. Jpn. Epil. Soc. $1997 ; 15: 1-6$

(received : May 31, 1996, 1st revised : July 26, 1996, 2nd revised: September 2, 1996, 3rd revised : October 7, accepted : October 7, 1996) 